\title{
Use of mulches and their effects on the radish crop
}

\author{
Jerffson L. Santos ${ }^{1}$, Cinira de A. F. Fernandes ${ }^{2}$, Luan S. Oliveira ${ }^{1}$, \\ Cristina M. de Jesus ${ }^{1}$, John S. Porto ${ }^{1} \&$ Tiyoko N. H. Rebouças ${ }^{1}$ \\ ${ }^{1}$ Universidade Estadual do Sudoeste da Bahia/Departamento de Fitotecnia e Zootecnia. Vitória da Conquista, BA. E-mail: je.lucas@hotmail.com \\ (Corresponding author); luanoliveirac@yahoo.com.br; crisiraj@hotmail.com; jsporto87@yahoo.com.br; tiyoko@uesb.edu.br \\ ${ }^{2}$ Instituto Federal de Educação, Ciência e Tecnologia Baiano/Campus Uruçuca. Uruçuca, BA. E-mail: cinira.farias@urucuca.ifbaiano.edu.br
}

\section{Key words: \\ Raphanus sativus \\ Leucaena leucocephala \\ Pterogyne nitens Tull \\ Panicum maximum \\ production}

\begin{abstract}
A B S T R A C T
This work aimed to evaluate the influence of green fertilization and the compost on the production of radish, cv. 'Cometa. The experimental design was randomized blocks with 6 treatments and 4 replicates: T1 - Leucaena, T2 - 'Madeira-nova', T3 - Compost (maize straw and composted cattle manure), T4 - 'Sempre verde' grass + compost and T5 - 'Sempre verde' grass and T6 - control without fertilization, totaling 24 experimental plots. The total area of the experimental plot was $1.44 \mathrm{~m}^{2}$, with useful area of $0.80 \mathrm{~m}^{2}$ and $21.0 \mathrm{t} \mathrm{ha}^{-1}$ of fertilizer (dry basis) were incorporated in each treatment. The radish crop was directly sown in the beds, in 2- to 3-cm-deep holes, leaving one plant at spacing of $20 \mathrm{~cm}$ between rows and $5 \mathrm{~cm}$ between plants. Twenty-nine days after planting, plants were evaluated for total yield, commercial yield, percentages of commercial roots (\%) and waste roots (\%), fresh and dry matter of shoots and roots, total and individual leaf area and the SPAD index. The incorporation of Leucaena at the amount of $21.0 \mathrm{t} \mathrm{ha}^{-1}$ (dry basis) promoted the highest increments for the analyzed characteristics.
\end{abstract}

Palavras-chave:

Raphanus sativus Leucaena leucocephala Pterogyne nitens Tull Panicum maximum produção

\section{Uso de coberturas mortas e seus efeitos para cultura do rabanete}

\section{R E S U M O}

Objetivou-se, neste estudo, avaliar a influência da adubação verde e do composto na produção do rabanete $\mathrm{cv}$. Cometa. $\mathrm{O}$ delineamento experimental adotado foi em blocos casualizados com 6 tratamentos e 4 repetições sendo T1 - Leucena, T2 - Madeira-nova, T3 - composto (palha de milho e esterco bovino compostado), T4 - capim sempre verde + palha de milho e esterco bovino compostado e T5 - capim sempre verde e T6 - testemunha sem adubação totalizando 24 parcelas experimentais. A área total da parcela experimental foi de $1,44 \mathrm{~m}^{2}$, com área útil de $0,80 \mathrm{~m}^{2}$ e para cada tratamento foram incorporadas 21,0 $\mathrm{t} \mathrm{ha}^{-1}$ de adubo em base seca. A semeadura do rabanete foi diretamente nos canteiros em berços de 2 a $3 \mathrm{~cm}$ de profundidade deixando uma planta no espaçamento de $20 \mathrm{~cm}$ entre linhas e $5 \mathrm{~cm}$ entre plantas; aos 29 dias após plantio foram avaliados a produtividade total, produtividade comercial, a porcentagem de raízes comercial (\%) e de refugo (\%), massa fresca e seca da parte aérea e das raízes, área foliar total e individual e o índice SPAD. A incorporação da leucaena na quantidade de $21,0 \mathrm{t} \mathrm{ha}^{-1} \mathrm{em}$ base seca ao solo proporcionou os maiores acréscimos para as características analisadas. 


\section{INTRODUCTION}

Radish (Raphanus sativus L.) is an herbaceous plant belonging to the Brassicaceae family that has globular roots and short cycle, between 25 and 30 days (Cardoso \& Hiraki, 2001; Paiva et al., 2013). In order to meet the requirement of large supplies of nutrients in relatively short periods, especially in tuberous vegetables, mineral fertilizers have been often used with exaggeration; thus, studies have been conducted aiming to provide alternatives that can meet the nutritional requirements of vegetable crops, minimizing the risks of contamination by chemical fertilizers in the production (Dantas et al., 2014).

Incorporated, the green fertilizer is one of the viable alternatives that have been used in the radish crop, contributing to the supply of nutrients required by the crop through the incorporation of undecomposed plant material, cultivated in the area and later incorporated to the soil. This practice results in the preservation and restoration of soil fertility and also contributes to the increase in the yields of the crops cultivated in these sites (Barros et al., 2013).

In the soil, this incorporation favors a higher aggregation, water retention and prevention of erosion, reducing losses through leaching due to a greater increment of organic matter along the years (Batista et al., 2012), thus contributing to the increase in the cation exchange capacity (CEC) of the soil and in the retention of nutrients close to its particles (Bonini et al., 2015), besides promoting improvement of soil physical and microbiological characteristics (Graham \& Haynes, 2006).

According to Dantas Júnior et al. (2014), there is a great demand for information that can provide assistance and support to radish producers with respect to its traditional fertilization and to the possibility of substitution of mineral fertilizers by other fertilization managements for the crop. Batista et al. (2013) point out that the use of spontaneous species from the Caatinga as green fertilizers is an alternative management technique for the production of vegetables in northeast Brazil, but there is still little information.

The study on the use of biomass of plant species as fertilization for vegetable production is important, because it allows the producer to perform fertilization using local inputs. According to Bonfim-Silva et al. (2011), the use of green fertilizers helps to minimize environmental impacts and decrease the excessive use of mineral fertilizers. Therefore, studies on fertilization have been conducted specifically for radish, aiming at the substitution of the traditional fertilization method used by the producer. Given the above, this study aimed to evaluate the effect of green fertilization and compost on the production of radish, cv. 'Cometa'.

\section{Material AND Methods}

The experiment was conducted at the campus of the State University of Southwestern Bahia (UESB) in a dystrophic Yellow Latosol with sandy clay loam texture (EMBRAPA, 2013), in the period from November to December 2014 in the municipality of Vitória da Conquista-BA (14 53' 09" S; $40^{\circ} 47^{\prime} 58^{\prime \prime} \mathrm{W}$; $941 \mathrm{~m}$ ). According to Köppen's classification, the climate of the region varies from sub-humid to semiarid and the mean annual temperature ranges from 19.5 to $20.5^{\circ} \mathrm{C}$.

The experimental design was randomized blocks with 6 treatments and 4 replicates, corresponding to different fertilizations using plant materials: T1 - Leucaena (Leucaena leucocephala), T2 - 'Madeira-nova' (Pterogyne nitens Tull), T3 - Compost (maize straw and composted cattle manure), T4 'Sempre verde' grass (Panicum maximum cv. 'Sempre verde'), T5 - 'Sempre verde' grass + compost and T6 - Control without fertilization, totaling 24 experimental units. The plant materials were collected at the experimental field of UESB in areas close to the experiment and were ground into pieces of $2-3 \mathrm{~cm}$, in a forage grinder, and later dried at ambient temperature until the point of hay (approximately four to five days).

The total area of the plot was $1.44 \mathrm{~m}^{2}$, with useful area of $0.80 \mathrm{~m}^{2}$. The radish cultivar used in the experiment was 'Cometa'. For each treatment, 21.0 t ha $^{-1}$ of fertilizer (dry basis) were incorporated according to the recommendation of Batista et al. (2013). The preparation of the soil in the experimental area consisted of one harrowing followed by manual raising of the beds using a hoe. Soil samples were collected using a soil auger in the beds in the layer of $0-20 \mathrm{~cm}$ and then subjected to chemical analysis to verify the level of nutrients before incorporating the organic fertilizers (Table 1).

The green fertilizers were applied and incorporated in the plots 21 days before sowing, mixed with the soil, in the layer of 0-20 cm (Linhares et al., 2009). Radish sowing was performed directly in the beds in 2- to 3-cm-deep holes. Three seeds were planted in each hole, and thinning was performed 9 days after sowing, leaving one plant at spacing of $20 \mathrm{~cm}$ between rows and $5 \mathrm{~cm}$ between plants. Irrigations were performed using sprinklers, in the morning for $1 \mathrm{~h}$.

Table 1. Soil chemical characterization before incorporating the green fertilizers and after harvesting the radish

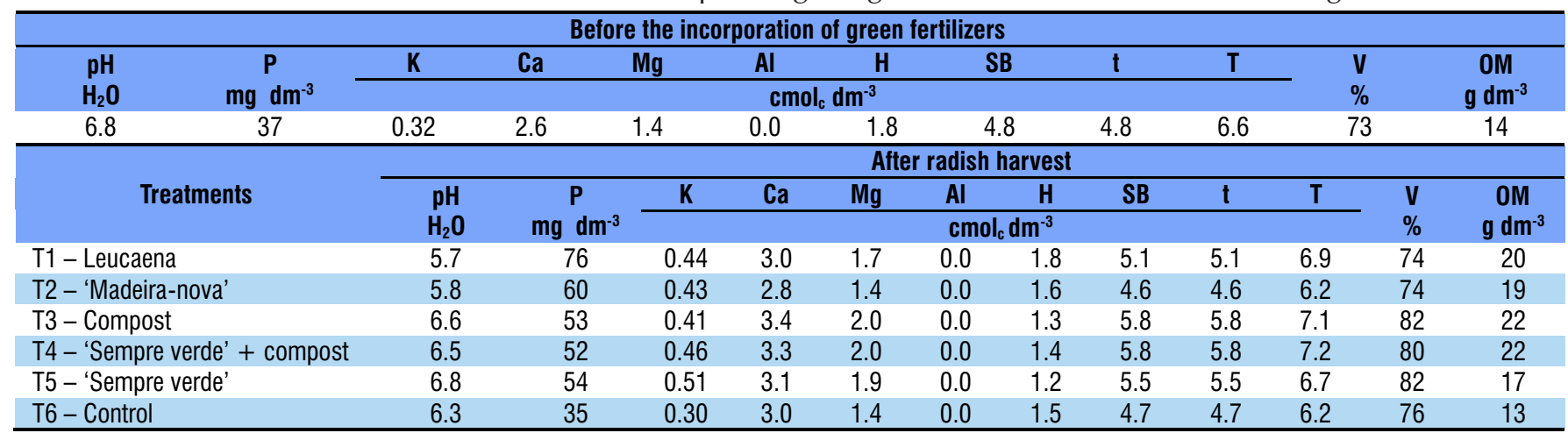

Source: Laboratory of Soils of the State University of Southwest Bahia; SB - Sum of exchangeable bases; $\mathrm{t}$ - effective cation exchange capacity (CEC); $T$ - potential CEC; $\mathrm{V}$ - Base saturation; $\mathrm{OM}$ - Organic matter 
At 29 days after planting, the useful area $\left(0.80 \mathrm{~m}^{2}\right)$ of each plot was harvested for the evaluation of the individual leaf area (ILA) of the $3^{\text {rd }}$ fully expanded leaf and total leaf area (TLA) of 6 plants using a leaf area integrator (LI-3100, LI-COR, USA), while the SPAD index was evaluated using a portable chlorophyll meter (SPAD-502, Minolta, Japan), in one fully expanded leaf at three different points.

In addition, the following variables were evaluated: shoot fresh and dry matter (SFM and SDM), root fresh and dry matter (RFM and RDM), total fresh and dry matter (TFM and TDM), total root yield (TRY) and percentage of commercial roots (\%CR) and waste roots (\%WR). Root dry matter (RDM) was determined in a sample of 20 plants and shoot dry matter (RDM) in the evaluated plants of the useful area, which were maintained in a forced-air oven at $65^{\circ} \mathrm{C}$ for $72 \mathrm{~h}$, until constant weight. The dry matter weight was determined using a precision scale $(0.001 \mathrm{~g})$.

At the end of the experiment, soil samples were collected in the layer of $0-20 \mathrm{~cm}$ for the determination of macronutrients, organic matter and $\mathrm{pH}$, after radish harvest (Table 1).

The data were subjected to tests of homogeneity of variance (Cochran and Bartlett) and normality (Lilliefors). Then, the evaluated variables were subjected to analysis of variance $(\mathrm{p}<$ $0.05)$ and the means were compared by Tukey test $(\mathrm{p}<0.05)$ using the program Sisvar 5.3 (Ferreira, 2011).

\section{Results AND Discussion}

There was an increase in soil fertility with increments of $40.7,33.4$ and $22 \%$ in the mean contents of $\mathrm{P}, \mathrm{K}$ and $\mathrm{Mg}$, respectively. Similar result was also observed in organic matter, with increment of $35 \%$ in its content in the soil, due to the incorporation of green fertilizers and organic compost in radish production (Table 1). Based on the studies conducted with green fertilization in the radish crop, the efficacy of this practice has been confirmed with the use of soil-conditioning and cover plants. Many studies have obtained positive results in the physical, chemical and biological aspects and greater availability of nutrients to the plant (Costa et al., 2006; Lima et al., 2008; Batista et al., 2013).

According to Lima et al. (2008), various beneficial effects can be promoted by green fertilization, including the increase in the availability of nutrients to the crops of commercial interest, protection of the soil against erosion, the favoring of organisms beneficial to agriculture and the control of spontaneous plants.

There were differences between the treatments for the analyzed characteristics (TLA, ILA, SPAD and SFM) (Table $2)$, with highest values of total leaf area $\left(133.99 \mathrm{~cm}^{2}\right)$ and shoot fresh matter $(8.86 \mathrm{~g})$ of radish for the incorporation of Leucaena. However, for individual leaf area and SPAD index, there were no significant differences in the comparison of incorporation of Leucaena and 'Madeira-nova' (ILA: 51.91, $49.96 \mathrm{~cm}^{2}$ and SPAD: $33.55,32.83$, respectively); nonetheless, the analyzed characteristics showed superior results with the use of leguminous plants, favoring greater stimulus to the vegetative development and accumulation of chlorophylls.

According to Oliveira et al. (2008), the highest accumulations of $\mathrm{N}$ in the plant residues were associated with the leguminous species, with beneficial effects of soil covers with leguminous
Table 2. Total leaf area (TLA), individual leaf area (ILA), SPAD index (SPAD) and shoot fresh matter (SFM) of radish plants under different organic fertilizers

\begin{tabular}{|c|c|c|c|c|}
\hline \multirow{2}{*}{ Treatments } & TLA & ILA & \multirow{2}{*}{ SPAD } & \multirow{2}{*}{$\begin{array}{c}\text { SFM } \\
\text { (g) }\end{array}$} \\
\hline & \multicolumn{2}{|c|}{$\left(\mathbf{c m}^{2}\right)$} & & \\
\hline T1 - Leucaena & $133.99 \mathrm{a}$ & $51.91 \mathrm{a}$ & $33.55 \mathrm{a}$ & $8.86 \mathrm{a}$ \\
\hline T2 - 'Madeira-nova' & $77.13 b$ & $49.96 \mathrm{a}$ & $32.83 \mathrm{a}$ & $5.70 \mathrm{~b}$ \\
\hline T3 - Compost & $62.35 b$ & $27.32 \mathrm{~b}$ & $28.50 \mathrm{~b}$ & $4.12 \mathrm{c}$ \\
\hline T4 - 'Sempre verde' + compost & $49.23 b$ & $24.99 \mathrm{~b}$ & $27.85 b$ & $3.11 \mathrm{~cd}$ \\
\hline T5 - 'Sempre verde' & $41.18 b$ & $20.60 \mathrm{~b}$ & $25.63 b$ & $1.99 \mathrm{~d}$ \\
\hline T6 - Control & $45.23 b$ & $24.54 \mathrm{~b}$ & $28.98 b$ & $3.56 \mathrm{c}$ \\
\hline Mean & 68.18 & 19.35 & 29.55 & 4.55 \\
\hline CV (\%) & 25.85 & 33.22 & 5.14 & 12.81 \\
\hline
\end{tabular}

*Means followed by the same letter in the column do not differ by Tukey test at 0.05 probability level

plants and bamboo, in the organic production of lettuce. The leguminous plants are the preferred ones as green fertilizers, because of the biological fixation of atmospheric $\mathrm{N}$ and the production of large amount of mass rich in nutrients that are essential to the plants (Lima et al., 2008).

There was an increment in the characteristics of mass accumulation (SDM; TFM; TDM) in the treatment with the use of Leucaena, in comparison to the others; however, these differences were not observed for RDM (Table 3). Although there were no high values for some nutrients in the soil when Leucaena was used (Table 1), the green fertilization with this leguminous plant allowed a greater biomass accumulation. According to Lima et al. (2008), the leguminous plants showed rapid mineralization, promoting a faster cycling of nutrients to the plants. Espindola et al. (2006) observed, in leguminous species, different patterns of decomposition of the plant residues and, consequently, release of nutrients, which can affect their availability to the main crop.

The low values of accumulation of fresh and dry matter when 'Sempre verde' grass was used (Table 3) can be related to the process of mineralization, favoring the immobilization of the nutrients, which occurred in the study of Espindola et al. (2006), in which the spontaneous vegetation formed by 'Colonião' grass caused the immobilization of $\mathrm{N}, \mathrm{Ca}$ and $\mathrm{Mg}$ in the plant residues for various months, which would lead to a competition for these nutrients with the main crop. Fontanétti et al. (2006), evaluating the absorption of nutrients from the mineralization by vegetables, point out that it mostly depends on the synchrony between the decomposition and mineralization of the plant residues and the period of highest nutritional demand of the crop.

Table 3. Shoot dry matter (SDM), root dry matter (RDM), total fresh matter (TFM) and total dry matter (TDM) of radish plants under different organic fertilizers

\begin{tabular}{lcccc}
\hline \multirow{2}{*}{ Treatments } & SDM & RDM & TFM & TDM \\
\cline { 2 - 5 } & \multicolumn{4}{c}{$\mathbf{( g )}$} \\
T1 - Leucaena & $0.82 \mathrm{a}$ & $0.78 \mathrm{a}$ & $22.80 \mathrm{a}$ & $1.60 \mathrm{a}$ \\
T2 - 'Madeira-nova' & $0.62 \mathrm{~b}$ & $0.61 \mathrm{abc}$ & $14.96 \mathrm{~b}$ & $1.23 \mathrm{~b}$ \\
T3 - Compost & $0.50 \mathrm{c}$ & $0.50 \mathrm{bcd}$ & $11.26 \mathrm{c}$ & $1.00 \mathrm{bc}$ \\
T4 - 'Sempre verde' + compost & $0.41 \mathrm{~cd}$ & $0.47 \mathrm{~cd}$ & $8.08 \mathrm{~cd}$ & $0.88 \mathrm{~cd}$ \\
T5 - 'Sempre verde' & $0.32 \mathrm{~d}$ & $0.38 \mathrm{~d}$ & $4.39 \mathrm{~d}$ & $0.71 \mathrm{~d}$ \\
T6 - Control & $0.46 \mathrm{c}$ & $0.65 \mathrm{ab}$ & $10.12 \mathrm{c}$ & $1.11 \mathrm{cb}$ \\
Mean & 0.52 & 0.56 & 11.93 & 1.09 \\
CV (\%) & 9.69 & 13.88 & 13.48 & 10.22 \\
\hline
\end{tabular}

*Means followed by the same letter in the column do not differ by Tukey test at 0.05 probability level 
Silva et al. (2006), working with different green fertilizers from crotalaria and millet produced with marked $\mathrm{N}\left({ }^{15} \mathrm{~N}\right)$ in the production of corn, observed that there was higher increment in the content of accumulated $\mathrm{N}$ and lower $\mathrm{C} / \mathrm{N}$ ratio in the leguminous species due to the high efficiency of the process of biological fixation that occurred in the crotalaria.

The mineralization process leads to energetic costs for the decomposers. Plants with lower $\mathrm{C} / \mathrm{N}$ ratio obviously have higher $\mathrm{N}$ content in their structure; therefore, there may be greater action of the decomposing microorganisms in plant material from leguminous species, due to the lower expenditure of energy required by the microorganisms involved in $\mathrm{OM}$ mineralization and $\mathrm{N}$ immobilization, in relation to plant materials that have composts with higher $\mathrm{C}$ density in their biomass, such as lignin (Monteiro et al., 2002).

For Toor et al. (2006), plants with low content of $\mathrm{N}$ and sufficient light for the normal photosynthetic rate may lead to an extra sequestration of $C$ in the excess photosynthesis, which can be allocated for the synthesis of secondary compounds of plant defense, such as the polyphenols, which can be a factor of inhibition to the mineralizing organisms.

There were significant differences between the treatments for the variables total yield and commercial yield and their highest values (13.94 and $10.53 \mathrm{t} \mathrm{ha}^{-1}$, respectively) were observed with the use of Leucaena (Table 4). Confirming the results found by Lima et al. (2008), in which the mineralization of organic matter in Leucaena occurred in time for the supply of nutrients to the radish crop. Similar result was also observed by Oliveira et al. (2010), studying the yield of lettuce and rocket under organic and mineral fertilization. Corroborating with Batista et al. (2013), when the radish crop was fertilized with 'jitirana' at the dose of $21.0 \mathrm{t} \mathrm{ha}^{-1}$, the total and commercial yields were 13.19 and $12.04 \mathrm{tha}^{-1}$, respectively.

For the percentages of commercial roots and waste roots, there were differences between the mean values obtained in the treatments (Table 4). The lowest percentages of commercial roots and the highest percentage of waste roots were observed for the use of the organic fertilizers 'Sempre verde' grass and 'Sempre verde' grass + compost. These results can be related to the fact that this grass species competes for $\mathrm{N}$ during the process of organic matter mineralization (Menezes \& Leandro, 2004), consequently affecting plant development and reducing the percentage of commercial roots and increasing the amount of waste roots produced by the radish plant.

Table 4. Total root yield (TRY), commercial root yield (CRY) and percentages of commercial roots (\%CR) and waste roots (\%WR) of radish plants under different organic fertilizers

\begin{tabular}{lccccc}
\hline \multirow{2}{*}{ Treatments } & \multicolumn{1}{c}{ TRY } & \multicolumn{1}{c}{ CRY } & & \%CR & \%WR \\
\cline { 2 - 3 } \cline { 5 - 6 } & \multicolumn{2}{c}{ (t ha- $\left.^{-1}\right)$} & & \multicolumn{2}{c}{ (\%) } \\
T1 - Leucaena & $13.94 \mathrm{a}$ & $10.53 \mathrm{a}$ & & $74.24 \mathrm{a}$ & $25.76 \mathrm{a}$ \\
T2 - 'Madeira-nova' & $9.26 \mathrm{~b}$ & $6.24 \mathrm{~b}$ & $54.59 \mathrm{a}$ & $45.41 \mathrm{a}$ \\
T3 - Compost & $7.14 \mathrm{bc}$ & $5.18 \mathrm{bc}$ & $55.94 \mathrm{a}$ & $44.06 \mathrm{a}$ \\
T4 - 'Sempre verde' + compost & $4.97 \mathrm{~cd}$ & $3.26 \mathrm{~cd}$ & $50.31 \mathrm{ab}$ & $49.69 \mathrm{ab}$ \\
T5 - 'Sempre verde' & $2.40 \mathrm{~d}$ & $1.43 \mathrm{~d}$ & $25.66 \mathrm{~b}$ & $74.34 \mathrm{~b}$ \\
T6 - Control & $6.56 \mathrm{bc}$ & $5.04 \mathrm{cb}$ & $59.38 \mathrm{a}$ & $40.62 \mathrm{a}$ \\
Mean & 7.38 & 5.28 & 53.35 & 46.65 \\
CV (\%) & 16.07 & 22.64 & 21.04 & 24.07 \\
\hline
\end{tabular}

*Means followed by the same letter in the column do not differ by Tukey test at 0.05 probability level

\section{Conclusion}

The incorporation of Leucaena at the amount of $21.0 \mathrm{tha}^{-1}$ (dry basis) to the soil promoted the highest increments in total yield, commercial yield and accumulation of shoot and root fresh and dry matter in the radish cultivar 'Cometa'.

\section{Literature Cited}

Barros, D. L.; Gomide, P. H. O.; Carvalho, G. J. Plantas de cobertura e seus efeitos na cultura em sucessão. Bioscience Journal, v.29, p.308-318, 2013.

Batista, M. A. V.; Bezerra Neto, F.; Ambrósio, M. M. Q.; Guimarães, L. M. S.; Saraiva, J. P. B.; Silva, M. L. Atributos microbiológicos do solo e produtividade de rabanete influenciados pelo uso de espécies espontâneas. Horticultura Brasileira, v.31, p.587-594, 2013.

Batista, M. A. V.; Vieira, L. A.; Souza, J. P.; Freitas, J. D. B.; Bezerra Neto, F. Efeito de diferentes fontes de adubação sobre a produção de alface no município de Iguatu - CE. Revista Caatinga, v.25, p.8-11, 2012.

Bonfim-Silva, E. M.; Silva, T. J. A. da; Guimarães, A. C. P. Desenvolvimento e produção de Crotalaria juncea adubada com cinza vegetal. Enciclopédia Biosfera, v.7, p.371-379, 2011.

Bonini, C. S. B.; Alves, M. C.; Montanari, R. Lodo de esgoto e adubação mineral na recuperação de atributos químicos de solo degradado. Revista Brasileira de Engenharia Agrícola e Ambiental, v.19, p.388-393, 2015. http://dx.doi.org/10.1590/1807-1929/agriambi. v19n4p388-393

Cardoso, A. I. I.; Hiraki, H. Avaliação de doses e épocas de aplicação de nitrato de cálcio em cobertura na cultura do rabanete. Horticultura Brasileira, v.19, p.196-199, 2001. http://dx.doi. org/10.1590/S0102-05362001000300007

Costa, C. C.; Oliveira, C. D.; Silva, C. J.; Timossi, P. C.; Leite, I. C. Crescimento, produtividade e qualidade de raízes de rabanete cultivadas sob diferentes fontes e doses de adubos orgânicos. Horticultura Brasileira, v.24, p.118-122, 2006. http://dx.doi. org/10.1590/S0102-05362006000100024

Dantas, I. L. A.; Faccioli, G. G.; Mendonça, L. C.; Nunes, T. P.; Viegas, P. R. A.; Santana, L. O. G. Viabilidade do uso de água residuária tratada na irrigação da cultura do rabanete (Raphanus sativus L.). Revista Ambiente e Água. v.9, p.109-117, 2014. http://dx.doi. org/10.4136/ambi-agua.1220

Dantas Júnior, G. J.; Silva, P. F. da; Matos, R. M. de; Borges, V. E.; Dantas Neto, J. Produção comercial de rabanete fertirrigado com nitrogênio em ambiente protegido. Revista Educação Agrícola Superior, v.29, p.99-104, 2014. http://dx.doi.org/10.12722/0101756X.v29n02a10

EMBRAPA - Empresa Brasileira de Pesquisa Agropecuária. Sistema brasileiro de classificação de solos. 3.ed. Brasília: EMBRAPA 2013. 353p.

Espindola, J. A. A.; Guerra, J. G. M.; Almeida, D. L. de; Teixeira, M. G.; Urquiaga, S. Decomposição e liberação de nutrientes acumulados em leguminosas herbáceas perenes consorciadas com bananeira. Revista Brasileira de Ciência do Solo, v.30, p.321-328, 2006. http:// dx.doi.org/10.1590/S0100-06832006000200012

Ferreira, D. F. Sisvar: A computer statistical analysis system. Ciência e Agrotecnologia, v.35, p.1039-1042, 2011. 
Fontanétti A.; Carvalho, G. J.; Gomes, L. A. A.; Almeida, K.; Moraes, S. R. G.; Teixeira, C. M. Adubação verde na produção orgânica de alface americana e repolho. Horticultura Brasileira, v.24, p.146150, 2006. http://dx.doi.org/10.1590/S0102-05362006000200004

Graham, M. H.; Haines, R. J. Organic matter status and the size, activity and metabolic diversity of the soil microbial community in the row and inter-row of sugar cane under burning a trash retention. Soil Biology \& Biochemistry, v.38, p.21-31. 2006. http:// dx.doi.org/10.1016/j.soilbio.2005.04.011

Lima, G. K. L. de; Linhares, P. C. F.; Bezerra Neto, F.; Paiva, A. P. M.; Maracajá, P. B. Uso de jitirana incorporada à adubação com esterco bovino na cultura da rúcula cv. folha larga. Revista Caatinga, v.21, p.135-139, 2008.

Linhares, P. C. F.; Silva, M. L.; Silva, U. L.; Silva, J. dos S.; Bezerra, A. K. H. Velocidade e tempo de decomposição da jitirana incorporada na cultura do rabanete. Revista Caatinga, v.22, p.213-217, 2009.

Menezes, L. A. S.; Leandro, W. M. Avaliação de espécies de coberturas do solo com potencial de uso em sistema de plantio direto. Pesquisa Agropecuária Tropical, v.34, p.173-180, 2004.

Monteiro, H. C. F.; Cantarutti, R. B.; Nascimento Júnior, D.; Regazzi, A. J.; Fonseca, D. M. Dinâmica de decomposição e mineralização de nitrogênio em função da qualidade de resíduos de gramíneas e leguminosas forrageiras. Revista Brasileira de Zootecnia, v.31, p.10921102, 2002. http://dx.doi.org/10.1590/S1516-35982002000500005
Oliveira, E. Q.; Souza, R. J.; Cruz, M. C. M.; Marques, V. B.; França, A. C. Produtividade de alface e rúcula, em sistema consorciado, sob adubação orgânica e mineral. Horticultura Brasileira, v.28, p.3640, 2010. http://dx.doi.org/10.1590/S0102-05362010000100007

Oliveira, F. F.; Guerra, J. G. M.; Almeida, D. L.; Ribeiro, R. L. D.; Espindola, J. A. A.; Ricci, M. S. F.; Ceddia, M. B. Avaliação de coberturas mortas em cultura de alface sob manejo orgânico. Horticultura Brasileira, v.26, p.216-220, 2008. http://dx.doi. org/10.1590/S0102-05362008000200017

Paiva, A. C. C.; Linhares, P. C. F.; Maracajá, P. B.; Pereira, M. F. S.; Alves, R. F.; Silva, E. B. R. da. Rabanete (Raphanus sativus L.) em sucessão aos cultivos de cenoura e coentro em sistema orgânico de produção. Agropecuária Científica do Semiárido, v.9, p.8893, 2013.

Silva, E. C.; Muraoka, T.; Buzetti, S.; Veloso, M. E. C.; Trivelin, P. C. O. Errata: Aproveitamento do nitrogênio $\left({ }^{15} \mathrm{~N}\right)$ da crotalária e do milheto pelo milho sob plantio direto em Latossolo Vermelho de Cerrado. Ciência Rural, v.36, p.739-746, 2006. http://dx.doi. org/10.1590/S0103-84782006000300004

Toor, R. K.; Savage, G. P.; Heeb, A. Influence of different types of fertilisers on the major antioxidant components of tomatoes. Journal of Food Composition and Analysis, v.19, p.20-27, 2006. http://dx.doi.org/10.1016/j.jfca.2005.03.003 